\title{
CrimRxiv
}

\section{Rampage Shootings and Gun Control: Politicization and Policy Change in Western Europe}

Steffen Hurka

Published on: May 17, 2017

DOI: $10.21428 / \mathrm{cb} 6 \mathrm{ab} 371.7576 \mathrm{~b} 5 \mathrm{ec}$

License: Creative Commons Attribution 4.0 International License (CC-BY 4.0). 
